https://nv.nltu.edu.ua

https://doi.org/10.15421/40280802

Article received 13.10.2018 p.

Article accepted 25.10.2018 p.

$@ \bowtie$ Correspondence author

удК 582.091/.099:712.253(477.4)

V. P. Masalskiy

vlad.masalskiy71@gmail.com

В. П. Масальський ${ }^{1}$, С. І. Кузнєцов ${ }^{2}$

${ }^{l}$ Білочерківський національний аграрний університет, м. Біла Церква, Украйна

${ }^{2}$ Національна академія керівних кадрів культури і мистещтв, м. Київ, Украӥна

\title{
АБОРИГЕННА ДЕНДРОФЛОРА ПОКРИТОНАСІННИХ - ОСНОВА ПАРКОБУДУВАННЯ В ЛІСОСТЕПУ УКРАЇНИ
}

Висвітлено результати досліджень складу насаджень дендрологічних парків Лісостепу України. Встановлено, що в складі насаджень парків кількісно переважають рослини аборигенних видів. Разом із дубом звичайним (Quercus robur L.) паркоутворювальну роль відіграють його супутники: клен гостролистий (Acer platanoides L.), ясен звичайний (Fraxinus exelsior L.), липа серцелиста (Tilia cordata Mill.), клен польовий (Acer campestre L.), клен явір (Acer pseudoplatanus L.), граб звичайний (Carpinus betulus L.), в'язові. Зроблено порівняльний аналіз аборигенної та інтродукованої дендрофлори в дендропарках Лісостепу України з таких критеріїв: функціональність, економічність та естетичність. 3 погляду функціональності доведено, що садово-паркові об'єкти, основу яких складають аборигенні види покритонасінних, легко створювати, за ними легко доглядати і такі об'єкти є більш довговічними. Доведено, що з економічного погляду парки, створені 3 покритонасінних аборигенної дендрофлори, є дешевшими за парки, створені з інтродуцентів у 10-15 разів. Встановлено, що парки, створені аборигенною дендрофлорою покритонасінних, мають найбільший позитивний психоемоційний вплив на відвідувачів і $€$ комфортними для відпочинку. Отже, для створення парків, аборигенна дендрофлора $є$ саме тим елементом ландшафту, який повною мірою відповідає основним трьом критеріям оцінки садово-паркового об'єкта, а значить $є$ головним паркоутворювальним елементом.

Ключові слова: вид; інтродуценти; грунтово-кліматичні умови; комфортні умови; функціональність; економічність; естетичність.

Вступ. Створення комфортних умов для життя, роботи і відпочинку в сучасному урбанізованому середовищі є першочерговим завданням сьогодення. Система озеленення населених місць передбачає створення об'єктів озеленення загального, обмеженого користування і спеціального призначення. При цьому значну долю участі в зелених насадженнях мають саме насадження загального користування: парки, сквери, бульвари, набережні. Якщо бульвари і набережні є "зеленими артеріями", через які свіже повітря поступає від прилеглих територій в місто, то парки є саме тим місцем, де відбуваються екологічні зміни: збагачення повітря киснем, фітонцидами, негативно зарядженими іонами; відбувається зниження критичних температур; зменшення негативного впливу вітру і шумового навантаження, тощо.

Парки є не тільки улюбленим місцем тривалого відпочинку городян а і місцем екологічної освіти. Тому парки є обов'язковим і незамінним елементом міської системи озеленення. При цьому видовому складу насаджень приділяється недостатньо уваги. Останнім часом, при доборі асортименту рослин при створенні парків, перевага хибно віддається екзотам, в той час, як традиційне використання аборигенних видів є більш раціональним з точки зору функціональності, економічності

та природної привабленності.

Актуальність теми дослідження. Ми спостерігаємо, що зона Лісостепу України - це найсприятливіша у грунтово-кліматичному відношенні для росту i розвитку більшості деревних і кущових рослин аборигенної дендрофлори, яку споконвіку використовували як основу дендрологічного складу паркових насаджень. Природні умови цієї зони були теж найкращими. Це стосується передусім листяних паркоутворювальних деревних порід. Але, на жаль, на практиці паркобудування це не завжди враховували. Так було і триває досі.

Останнім часом під час створення об'єктів озеленення (з метою створити щось незвичайне, епатажне) дедалі частіше використовують інтродуценти, відсуваючи на другий план рідну нам аборигенну дендрофлору. Тому щоразу частіше бачимо на вулицях, бульварах, прибудинкових і промислових територіях міст декоративні види і форми інтродукованих деревних рослин, і ця тенденція почала поширюватись на садово-паркові об'єкти. Тому є актуальним довести незамінну роль саме аборигенної дендрофлори покритонасінних у паркобудуванні. Що стосується хвойних, то це окрема тема для дискусії.

Мета і завдання дослідження. На підставі проведених досліджень і аналізу літературних джерел довести

Інформація про авторів:

Масальський Владислав Петрович, канд. біол. наук, доцент, кафедра садово-паркового господарства.

Email: vlad.masalskiy71@gmail.com

Кузнєцов Сергій Іванович, д-р біол. наук, професор, кафедра дизайну середовища. Email: cedrusk90@gmail.com

Цитування за ДСтУ: Масальський В. П., Кузнєцов С. І. Аборигенна дендрофлора покритонасінних- основа паркобудування в лісостепу України. Науковий вісник НЛтУ України. 2018, т. 28, № 8. С. 14-18.

Citation APA: Masalskiy, V. P., \& Kuznetsov, S. І. (2018). Angiosperms aboriginal dendroflora as the basis for parks establishment in the forest-steppe of Ukraine. Scientific Bulletin of UNFU, 28(8), 14-18. https://doi.org/10.15421/40280802 
роль аборигенної дендрофлори покритонасінних як основи паркобудування в умовах Лісостепу України.

Умови дослідження проводились на прикладах садово-паркових об'єктів України: дендрологічні парки "Олександрія", "Софіївка", "Тростянець", "Качанівка", "Сокиринці", а також "Сирецький парк".

Об'єкт дослідження - аборигенна дендрофлора покритонасінних, інтродуценти.

Методика проведення досліду. Порівняльний аналіз таксономічного складу видів рослин аборигенної і інтродукованої дендрофлори та методів і підходів під час їх використання у паркобудівництві.

Результати дослідження та їх обговорення. У сучасній системі озеленення населених місць парки мають особливе місце. Це найбільші об'єкти озеленення, адже за сучасною класифікацією мінімальна площа парків становить 6 га. Як відомо, чим більший деревний масив, тим більші екологічні зміни (такі необхідні для сучасних населених місць) відбуваються для покращення (Kucherjavij, 2008; Lunc, 1974). Отже, парки є не тільки невід'ємною частиною міської системи озеленення, а й є незамінним іiї елементом. Аналіз досвіду багаторічного використання аборигенних та інтродукованих рослин у старовинних дендропарках і парках України дає змогу зробити певні висновки і прогнози.

Найпоширенішими паркоутворювальними видами 3 хвойних деревних рослин $\epsilon$ сосна звичайна (Pinus sylvestris L.), ялина звичайна (Picea abies (L.) H. Karst.), сосна чорна (Pinus nigra Arn.). Насадження сосни звичайної деколи є залишками природних лісів, інколи посадками. Інші види - інтродуценти, їх насадження штучного походження. Досить часто в паркобудуванні використовують сосну Веймутову (Pinus strobus L.), ялину колючу (Picea pungens Engelm.), модрину європейську (Larix decidua Mill.), тую західну (Thuja осcidentalis L.), ялівець козацький (Juniperus sabina L.). Отже, 3 хвойних головними видами для створення паркових ландшафтів $\epsilon$ і залишаються екзоти. Вони вже досягли значних розмірів і вступили в пору свого максимального розвитку.

Інше становище 3 видами листяних деревних рослин. Як у сучасних, так і в старовинних дендропарках кількісно переважають рослини аборигенних видів. Це пов'язано $з$ тим, що більшість парків рівнинної частини України створювали на підстаі природних дібров корінного типу лісу Лісостепу України. Разом із дубом звичайним (Quercus robur L.) важливу роль, як паркоутворювальні види, відіграють його супутники: клен гостролистий (Acer platanoides L.), ясен звичайний (Fraxinus exelsior L.), липа серцелиста (Tilia cordata Mill.), клен польовий (Acer campestre L.), клен явір (Acer pseudoplatanus L.), граб звичайний (Carpinus betulus L.), в'язові. Ці види становлять основу паркових насаджень зони Лісостепу України (Kuznetsov, 2011). Згідно з основним принципом створення садово-паркових об'єктів, парки мають бути: функціональними, економічними, естетичними (Rubtsov, 1964).

Функиіональні насадження - це об'єкти, які легко створювати, за якими легко доглядати, а головне - вони довговічні. Довговічність паркових насаджень залежить не тільки від індивідуальної довговічності дерев кожного виду, а насамперед від відповідності дерев грунтовим і кліматичним умовам створюваного об'єкта.
Аборигенні види тисячоліттями пристосовувалися до грунтово-кліматичних умов місцезростання. Відбувався природний відбір якостей і відмінностей, які сприяли найбільшому ступеню пристосування рослин до умов цього регіону. Під впливом середовища відбулися фізіологічні, анатомічні та морфологічні зміни, які дали змогу аборигенним видам вижити в конкурентній боротьбі. Ці рослини пристосувались до співіснування один 3 одним, тобто утворили біо- і фітоценози, які сприяли виживанню цих рослин у відповідних умовах (Klimenko, 2015; Rubtsov, 1977; Kuznetsov, 2011).

У сучасних реаліях парки можуть бути створені двома способами. Перший - це використання існуючих лісових насаджень 3 переводом їх у паркову зону. У таких випадках зазвичай насадження уже створені переважно з рослин аборигенних деревних видів. Адже лісівники мають віковий досвід ефективного використання лісових ресурсів, підбору деревних видів відповідно до грунтово-кліматичних умов регіону та створення благоприємних біоценозів для отримання найкращого результату. Звісно, інколи в лісових насадженнях можемо побачити лісові культури дуба червоного (Quercus borealis Michx.), ясена зеленого (Fraxinus lanceolata Borkh.), бархата амурського (Phellodendron amurense Rupr.) тощо. Але використання інтродуцентів у лісових насадженнях $є$ більше винятком, ніж правилом. На практиці інтродуценти показали меншу довговічність. Так, відомо, що аборигенний дуб черешковий (Quercus robur L.) навіть у міських умовах доживає до 100150 років, а інколи - до 300-400 років, водночас, дуб червоний показує значно меншу довговічність (до 100 років). Двохсотрічний досвід інтродукції деревних рослин в Україні показав, що зазвичай довговічність екзотів у культурі в 1,5-2,0 рази менша, ніж у природних умовах (Kuznetsov, 2011).

Часто інтродуценти не досягають того розміру, якого досягають аборигенні види, як наприклад, ясен зелений порівняно 3 ясеном звичайним (Fraxinus exelsior L.). При цьому зовнішній вигляд інтродуцентів (габітус) виглядає недорозвиненим, не має таку красиву, розвинену форму крони.

Інтродуценти мають значно гірші показники фізикомеханічних властивостей деревини, що не може не позначитися на декоративності та довговічності дерева. Так, сосна веймутова (Pinus srobus L.) має значно крихкішу деревину, ніж аборигенна сосна звичайна (Pinus sylvestris L.). Це призводить до періодичного пошкодження скелетного гілля снігом, що позначається на декоративному вигляді дерева (приклад - найстаріша в Україні сосна Веймутова в дендропарку "Олександрія"). Як наслідок, у місця пошкоджень потрапляють збудники хвороб, а це призводить до зниження довговічності дерева.

Другий спосіб створення сучасного парку - це його проектування та створення. Для цього під час проектування необхідно зробити добір видового складу насаджень. Отож, в основу видового складу парків необхідно планувати саме аборигенні види дендрофлори. При цьому проектанту під час створення парків не треба навіть нічого вигадувати. Треба продумати як максимально скопіювати природу, а саме передусім скопіювати видовий склад деревно-чагарникової і навіть трав'янистої рослинності. Такий добір рослин допоможе створити квазіприродні біоценози. 
Завдяки біоценозам, що утворяться за подібного добору, догляд за цими насадженнями буде зведений до мінімуму, а такого буде підвищена довговічність такого садово-паркового об'єкта. Інтродуценти ж у таких масивних штучних насадженнях мають відігравати другорядну роль, виступати як родзинки, щоб прикрашати, урізноманітнювати насадження і вражати відвідувачів.

Занадто велика кількість інтродуцентів може призвести до конкурентної боротьби між рослинами. Якщо ця боротьба між аборигенними видами відбувалася протягом тисячоліть і в цій боротьбі утворився певний баланс, то надмірне використання інтродуцентів може призвести до небажаних наслідків. Інтродуценти можуть пройти не тільки акліматизацію, а й досягнути ступеня натуралізації і вступити в конкурентну боротьбу з аборигенними видами, як ми це бачимо по всій Україні на прикладі клена ясенелистого (Acer negundo L.). Подібне може призвести до порушення біоценозів і, як наслідок, до нової конкурентної боротьби, що не може не вплинути на функціональність садово-паркових об'єктів.

Прикладами парків, в основі яких є аборигенні види деревних рослин в Україні, можуть бути дендропарки "Олександрія", "Софіївка", "Качанівка", "Сокиринці" та багато інших старовинних парків, які та були створені саме за таким принципом.

Відповідно до принципу економічності, найкращим витвором мистецтва $\epsilon$ той, що за найменших витрат коштів набуває найбільшого декоративного та економічного ефекту. Садово-паркове будівництво - дороге і трудомістке мистецтво. Воно потребує великих витрат не тільки під час створення того чи іншого об'єкта, а й протягом усього періоду існування. Тому необхідно проектувати зелені насадження так, щоб їх створення і подальший догляд за ними були якомога дешевшими. На думку Л. І. Рубцова, цього можна досягти двома способами: по-перше - збільшенням рівня механізації будівельних робіт; по-друге - створенням таких композицій дерев, кущів і трав'янистих рослин, які б грунтувалися на властивих їм біологічних закономірностях і відповідали екологічним і ценотичним вимогам рослин, що входять у композицію.

Стосовно механізації виробничих процесів навряд чи можливо істотно знизити витрати на створення парків за такий рахунок. Адже під час створення парків ми використовуємо наявну в господарстві техніку або ту, яка доступна. Тому на рівень механізації не можемо вплинути під час проектування парку. Натомість добір рослин для створення парку є прерогативою проектувальника.

У випадку добору видового складу під час створення парків, керуючись функціональністю об'єкта, потрібно робити акцент саме на аборигенні види, адже великомірний садивний матеріал аборигенних видів можна придбати на місцевих розсадниках та в лісгоспах. Інтродуценти ж переважно закуповують у садових центрах, а ті закуповують їх за кордоном і ще, надають своєї націнки. Тому вартість інтродуцентів буде у декілька разів вищою, ніж аборигенних видів аналогічної якості, придбаних у місцевих розсадниках.

Різниця в ціні на великомірний садивний матеріал аборигенної дендрофлори 3 місцевих розсадників, порівняно 3 інтродуцентами 3 садових центрів, досить значна, а інколи різниця у вартості доходить до суми, яка в 10 і навіть у 20 разів перевищує вартість аборигенних видів.
У деяких вітчизняних розсадниках великомірний садивний матеріал вважають перерослим, який не має попит, тому що його викопування і пересадка $є$ трудомісткою і доволі коштовною. У таких підприємств великомірний садивний матеріал можна придбати взагалі за безцінь, а в деяких випадках - навіть за очищення території. Ця економія на закупівлі вітчизняного садивного матеріалу аборигенної дендрофлори значно знижує кінцеву суму вартості садово-паркового об'єкта.

Коли йдеться про ландшафтну структуру парку, коли потрібно урізноманітнити видовий склад, підкреслити рослинну композицію, показати індивідуальну красу однієї рослини (солітер) на поляні, в таких випадках великі затрати на декоративні інтродуценти цілком виправдані, адже такі рішення потребують невеликої кількості інтродукованого декоративного садивного матеріалу. У випадку, коли треба створити основу парку, без сумніву, треба використовувати садивний матеріал аборигенної дендрофлори вітчизняного виробництва. Адже щоб об'єкт не виглядав незакінченим рідколіссям, необхідно використовувати великомірні рослини заввишки 3-4,5 м 3 добре розвиненою кроною. На одне посадкове місце для таких рослин треба передбачити 9-10 м², тобто 1000 дерев на 1 га. 3 урахуванням того, що за сучасною класифікацією мінімальна площа парку становить 6 га, то на створення такого маленького парку знадобиться 6000 дерев. У грошовому еквіваленті різниця сум на створення такого маленького парку з аборигенних видів із місцевих розсадників і інтродуцентів зі садових центрів може становити 5000000 грн і навіть більше.

До того ж садивний матеріал, який придбано на місцевих розсадниках, є можливістю якісно і насамперед швидко їх пересадити. Адже від якості та швидкості виконання подібних робіт залежить процент приживлюваності. Чим швидше викопану рослину буде посаджено в грунт, тим більша вірогідність ії приживлення, а отже, збільшується частка дерев, що прижилися. Відповідно зменшується кількість рослин, необхідних на пересадку на місця загиблих. А це є прямим зниженням матеріальних витрат. Садивний матеріал, придбаний в садових центрах (інтродуценти), навіть якісно викопаний і упакований з грудкою, тривало перебуває в обмеженій кількості грунту, пересихає (у грудці - недостатня кількість вологи і поживних речовин). Це не може не позначитися на проценті приживлюваності великомірного садивного матеріалу, а відповідно - і на вартості всього об'єкта.

Ще один важливий показник, який впливає на витрати, - це догляд за об'єктом. 3 погляду економічності об'єкта, добір рослин відповідно до грунтово-кліматичних умов регіону і створення біоценозів потребує значно менших затрат на догляд за насадженнями, створеними 3 аборигенних видів деревних рослин, ніж подібний об'єкт, створений з інтродуцентів. Інтродуценти намагаємося використовувати в умовах максимально наближених до їх природних. Але нові грунтово-кліматичні умови не завжди задовольняють повною мірою потребам інтродукованих рослин. Тому ці рослини потребують додаткового догляду, що призводить до подорожчання утримання об'єкта. Передусім це матеріальні витрати на добрива та підкислювачі (як у випадку з рододендронами) тощо, а також на додаткові витрати за виконану роботу щодо догляду за об'єктом. 
Враховуючи той факт, що парки $є$ найбільшими штучними об'єктами, озеленення стає очевидним з економічного погляду, що альтернативи аборигенній флоpi, як основі паркобудування, не існує.

Третій критерій - естетичність. Він потребує, щоб проектований зелений об'єкт не тільки задовольняв поставленим цілям і був економічний, а й став витвором мистецтва, який повинен впливати на почуття людини сприятливо та у виховному плані.

Естетичність - це найбільш суперечливий критерій оцінювання. Скільки людей - стільки і смаків. Тому потрібно виходити з функціонального призначення парків і їх основного соціального завдання. Основним соціальним завданням парків $є$ створення комфортних умов для тривалого відпочинку громадян. Відповідно до цього завдання, треба вирішувати не тільки питання формування ландшафтів: рельєфу, співвідношення закритих і відкритих просторів, водойм, а насамперед, провести такий добір рослин видового складу, який би був комфортним для душі та менталітету відвідувачів, тобто для відпочинку (рекреації).

Композиції, створені з інтродукованих рослин, $є$ такими, що виходять за межі повсякденності. Вони вражають своїм незвичним виглядом, великими квітами (магнолії, кампсиси, рододендрони), великим і різним за формою листям (катальпа, павлонія, сумах пухнастий), різноманітним за кольором листям (бук, свидина), дивовижними плодами (маклюра, катальпа, платан) тощо. Такі композиції вражають, як-то кажуть, епатують відвідувачів. Таке велике біорізноманіття, їх добір, компонування, формування і їх вигідна презентація - це функціональне завдання ботанічних садів. Соціальною метою парків є створення теплих, комфортних, затишних умов, які б нагадували краєвиди з дитинства. Саме в таких умовах людина може почуватися частинкою природи i, відповідно, відновлювати свій емоційний, психологічний і фізичний стан.

Краєвиди дитинства надихали колишніх садівників створювати справжні витвори садово-паркового мистецтва. За таким принципом було створено "Велику поляну" в дендрологічному парку "Олександрія" НАНУ. Олександра Браницька замовила садівникам створити поляну, яка б нагадувала своїми краєвидами і видовим складом їі рідну Смоленщину. I садівники успішно виконали її завдання. Такий підхід, з погляду естетичності, має бути основою створення парків.

Усі три принципи - функціональність, економічність і естетичність - взаємопов'язані між собою і порушення одного з них негативно позначається на двох інших, а отже, і на всьому об'єкті, що проектується. Отже, для створення парків, аборигенна дендрофлора $\epsilon$ саме тим елементом ландшафту, який повною мірою відповідає цим трьом критеріям оцінки садово-паркового об'єкта.

Висновки. На підставі проведеного порівняльного аналізу використання аборигенної та інтродукованої дендрофлори в паркобудуванні можна зробити такі висновки:

1. Функціональні садово-паркові об'єкти, створені на підстаі добору рослин за біоценотичним принципом, відрізняються підвищеною довговічністю, їх легко створювати і доглядати. Основою добору видового складу парків Лісостепу України мають бути покритонасінні аборигенної дендрофлори.

2. Парки, створені з покритонасінних аборигенної дендрофлори, імітують природні ландшафти зони Лісостепу, тому є позитивними для психоемоційного стану відвідувачів і $є$ комфортними для відпочинку.

3. Використання інтродуцентів, особливо хвойних, не тільки можливе, а й необхідне і корисне, але воно повинно бути в найбільш відвідуваних, "парадних" місцях і потребує подальших досліджень.

4. 3 економічного погляду парки, створені з покритонасінних аборигенної дендрофлори, є дешевшими за парки, створені з інтродуцентів у 10-15 разів.

Отже, покритонасінні аборигенної дендрофлори 3 біологічного, практичного і естетичного поглядів $\epsilon$ головним паркоутворювальним елементом, альтернативи якому не існує.

\section{Перелік використаних джерел}

Klimenko, Yu. O. (2015). Zagalne parkoznavstvo (IstorichnI, bIologo-ekologIchnI, landshaftno-lIsIvnichI pIdhodi ta metodi). Kyiv: Komprint, 416 p. [In Ukrainian].

Kucherjavij, V. P. (2008). Ozelenennja naselenih misc': Pidruchnik. L'viv: Svit, 456 p. [In Ukrainian].

Kuznetsov, S. I. (2011). Parkoznavstvo. Navchalniy posIbnik. Kyiv: Kompring, 156 p. [In Ukrainian].

Lunc, L. B. (1974). Gorodskoe zelenoe stroitel'stvo. Moscow: Strojiztat, 275 p. [In Russian].

Rubtsov, L. I. (1964). Proektirovanie sadov $i$ parkov. Moscow: Publishing Literaturyi po stroitelstvu, 236 p. [In Russian].

Rubtsov, L. I. (1977). Derevya i kustarniki v landshaftnoy arhitekture. Kyiv: Scientific thought, 272 p. [In Russian].

В. П. Масальский1, С. И. Кузнецов²

${ }^{1}$ Белоиерковский национальный аграрный университет, г. Белая Церковь, Украина ${ }^{2}$ Национальная академия руководящих кадров культуры и искусства, г. Киев, Украина

\section{АБОРИГЕННАЯ ДЕНДРОФЛОРА ПОКРЫТОСЕМЕННЫХ - ОСНОВА ПАРКОСТРОЕНИЯ} В ЛЕСОСТЕПИ УКРАИНЫ

\footnotetext{
Отражены результаты исследований состава насаждений дендрологических парков Лесостепи Украины. Установлено, что в составе насаждений парков количественно преобладают растения аборигенных видов. Вместе с дубом черешчатым (Quercus robur L.) паркообразущую роль играют его спутники: клен остролистный (Acer platanoides L.), ясень обыкновенный (Fraxinus exelsior L.), липа сердцелистная (Tilia cordata Mill.), клен полевой (Acer campestre L.), клен явор (Acer pseudoplatanus L.), граб обыкновенный (Carpinus betulus L.), вязовые. Проведен сравнительный анализ аборигенной и интродуцированной дендрофлоры в дендропарках Лесостепи Украины по таким критериям: функциональность, экономичность и эстетичность. С точки зрения функциональности доказано, что садово-парковые объекты, основу которых составляют аборигенные виды покрытосеменных, легко создавать, за ними легко ухаживать и такие объекты являются более долговечными. Доказано, что с экономической точки зрения парки, созданные из покрытосеменных аборигенной дендрофлоры, дешевле парков, созданных из интродуцентов, в 10-15 раз. Установлено, что парки, созданные аборигенной дендрофлорой покрытосеменных, имеют наибольшее положительное психоэмоциональное воздействие на посетителей и являются комфортными для отдыха. Таким образом, для создания парков аборигенная дендрофлора является именно тем элементом ландшафта, ко-
} 
торый в полной мере соответствует основным трем критериям оценки садово-паркового объекта, а значит является главным паркообразующим элементом.

Ключевые слова: вид; интродуценты; почвенно-климатические условия; комфортные условия; функциональность; экономичность; эстетичность.

V. P. Masalskiy1, S. I. Kuznetsov ${ }^{2}$

${ }^{1}$ Bila Tserkva National Agrarian University, Bila Tserkva, Ukraine

${ }^{2}$ National Academy of Cultural and Arts Management, Kiev, Ukraine

\section{ANGIOSPERMS ABORIGINAL DENDROFLORA AS THE BASIS FOR PARKS ESTABLISHMENT} IN THE FOREST-STEPPE OF UKRAINE

The paper highlights the results of the research on the composition of dendrological parks plantings in the forest-steppe of Ukraine. The authors have found out that aboriginal species of plants dominate quantitatively in the composition of parks plantations. This is due to the fact that most parks of the plain part of Ukraine were established on the basis of natural ridges of the rooted forest type. Along with common oak (Quercus robur L.), its satellites such as acerlic (Acer platanoides L.), common ash (Fraxinus exelsior L.), heart-leaf linden (Tilia cordata Mill.), field maple (Acer campestre L.), maple (Acer pseudoplatanus L.), common hornbeam (Carpinus betulus L.) and elms form the park greenery. These species make the basis of park plantations in the forest-steppe zone of Ukraine. A comparative analysis of aboriginal and introduced dendroflora in the arboretums of the forest-steppe of Ukraine is made on the following criteria: functionality, economy and aesthetics. From the point of view of the functionality, it has been proved that parks and gardens objects, with aboriginal angiosperm species selected according to the biocenotic principle, make the basis of the parks plants. These plants are easy to create and care for, and such objects are also more durable since the two hundred year experience of introducing tree plants in Ukraine has proved that the longevity of exotic cultures is 1.5-2,0 times less than that in natural conditions. Therefore, the park plantations the basis of which is represented by aboriginal species of angiosperms are the most functional. It is proved that from an economic point of view, parks consisting of aboriginal angiosperms dendroflora are 10-15 times cheaper than parks created from introduced species. The influence of garden-park objects created by aboriginal dendroflora of angiosperms from the point of view of aesthetics is estimated. It is found out that such parks simulate the natural landscapes of the forest-steppe zone, therefore they have the greatest positive psycho-emotional impact on visitors and are comfortable for relaxation. Thus, aboriginal dendroflora is just the parks creation element of the landscape which fully meets the requirements of the three basic criteria for assessing the gardening object, and, therefore, is the main park-forming element that cannot be substituted.

Keywords: species; introduents; soil and climatic conditions; comfortable conditions; functionality; economic efficiency, aesthetic value. 